\title{
Methods, Techniques and Approaches to Post-War Architectural Reconstruction
}

\author{
Hana Cicevic \\ School of Architecture, University of Florida \\ Faculty mentor: Lisa Huang, School of Architecture
}

\begin{abstract}
This research explores similarities and differences between techniques and approaches to post-war architectural reconstruction. An overview of various different social, political and cultural difficulties and obstacles that architects needed to consider while making adequate design proposals will be presented and discussed. The research population who are intimately and emotionally connected with the pre-war design. The main empirical method is through case studies, examining a variety of different architectural structures that were reconstructed following the armed conflicts. The research is not limited to a single time period or a single geographical zone; it will analyze and synthesize findings from various different cultural and regional environments. Case studies will include examination of Dresden Frauenkirche (Germany), Atomic Bomb Dome (Japan), Neues Museum (Germany) and Cadiz Castle (Spain). The study strives to extract the guiding principles of reconstruction, sorting them into several different overall techniques: faithful reconstruction, intervention, patching and passive monument creation. However, the research does not favor one technique over the other, instead it offers a critical overview of their implementation and suitability for reconstruction by considering given cultural and social circumstances.
\end{abstract}

Keywords: war architecture; reconstruction; renovation

\section{Introduction}

As humans, we tend to consider ourselves superior, highly intellectual beings. Yet, even in modern era, our society fails in its attempts to eliminate one of its most primitive inventions: warfare $^{1}$. Primarily, every warfare directly impacts the human built environment through architectural destruction. When war ends, buildings become ruins, leaving the common man deprived of shelter and necessary cultural and educational institutions. In order to bring the scarred community back on its feet, it is first necessary to restore the normal living conditions.

This is the moment when architects take on the social burden by utilizing architectural design as a vehicle for rebuilding and reshaping new, post-war societies. As this task is not, by any means, simple, countless design, moral and ethical questions can be associated with it. The first question addresses the public acceptance of the new design. This question will be discussed in this research with the aid of examples that were characterized by public involvement. 
Furthermore, the second issue concentrates on the question of what materials, techniques and methods are appropriate in the process of post-war reconstruction. The study will strive to answer this question by offering a variety of examples that represent different approaches to reconstruction. These approaches will be classified into four different subgroups including: faithful reconstruction, reconstruction with intervention elements, "patching" and passive shift to making peace/war monuments.

\section{Overview of Lebbeus Woods reconstruction theories}

This research is by a great extent influenced by the work and philosophy of American theoretical architect Lebbeus Woods. His work offers an excellent overview of theories, approaches and problems of post-war reconstruction. Moreover his work is immensely valuable to this study because Lebbeus Woods also addresses the issue of general public acceptance of post-war reconstruction designs. Lebbeus Woods's reconstruction suggestions are purely theoretical, to a certain extent, even science-fictional and impossible to build.

In his work War and Architecture, Woods presents A Case Against Restoration and A Case Against Erasure. Woods states that while "It is natural to want to erase the memories of tragedy and loss, to substitute for the fabric of the city that has been destroyed and degraded by violence an entirely new tissue, and a better one."2, "The attempt to restore the fabric of old cities to their former condition is, however, a folly that not only denies present conditions, but impedes the emergence of an urban fabric and way of life based upon them."3

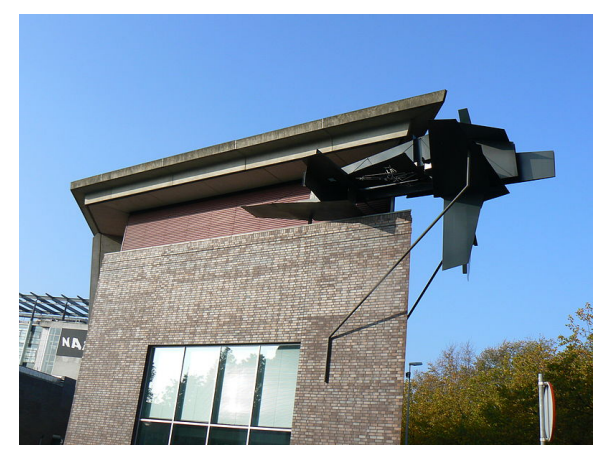

Figure 1. Sculpture Design by Lebbeus Woods. 1998. Source: https://upload.wikimedia.org/wikipedia/commons/thumb/d/d6/Rotterdam_Woods_01.JPG/800pxRotterdam_Woods_01.JPG.

In his writing, Woods argues that the aim of post-war reconstruction is to dignify and honor history and victims of the past times. 


\section{Case Study 1: Dresden Frauenkirche}

Featuring one of the largest domes in the world, at the time of construction, Dresden Frauenkirche became a great wonder of engineering and a major symbol of Dresden pride. The original importance of this structure will play a significant role in the reconstruction planning decisions.

Following the end of World War II, the ruin of the Church remained intact for 45 years. Dresden became a part of the German Democratic Republic (East Germany). As a part of the Eastern Block, GDR officially aligned with communist ideology, a system that did not see religion as a high-priority state matter. In accordance with its political principles, the GDR government prioritized investing in public and utilitarian rather than in religious institution reconstruction. ${ }^{4}$

Given this inability and unwillingness for undertaking architectural reconstruction, the GDR Government decided to, instead, utilize the ruins by turning them into a "memorial of the war". Following the bombing of 1945, only a couple of walls from the original structure remained standing and those walls, intact, became a symbol of GDR Dresden that changed city's urban landscape. This passive observation of the ruin for a prolonged period of time, can be seen as one of the approaches of addressing the issue which can also be noticed in the example of Atomic Bomb Dome that will be discussed in the next case study.

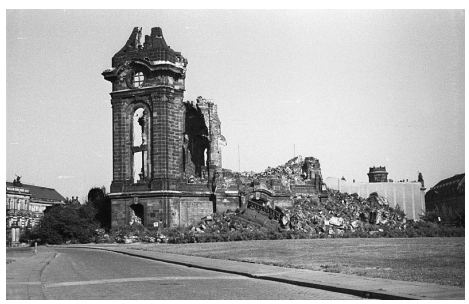

Figure 2. Remains of Dresden Frauenkirche: Dresden, Germany. Cca. 1970. Source: https://upload.wikimedia.org/wikipedia/commons/5/5f/Drezda\%2C_N\%C3\%A9metorsz\%C3\%A1g._A_Miasszonyunktemplom_\%28Frauenkirche\%29_romjai._Fortepan_50167.jpg.

The Frauenkirche reconstruction was marked by a great public interest and active involvement. Older Dresden residents still recalled the original Frauenkirche as it was decades ago and its great importance as the city's symbol and pride, and therefore, they could simply not accept a ruin, or "memorial of the war", in place of such a magnificent structure. As this idealized image of Dresden Frauenkirche was passed to the younger generations, the ruins became a symbol of nostalgia and longing for the past times. Consequently, the public masses demanded for the 
faithful reconstruction that would measure up to the original Church's brilliance. ${ }^{5}$ Thus, soon after the fall of Berlin Wall and German reunification, the Society to Promote the Reconstruction of the Church of Our Lady, representing the people of Dresden, started the fund gathering action towards the aim of rebuilding Frauenkirche. ${ }^{6}$

During the Dresden bombing of 1945, the Church's main structure was not able to endure the extremely high temperature consequent of the fire which lead to its collapse. The fire permanently damaged the exterior stone, altering its appearance and color to a darker shade of grey. The variation of color from the new stone's light grey and damaged stone's dark grey became one of the crucial reconstruction design factors.

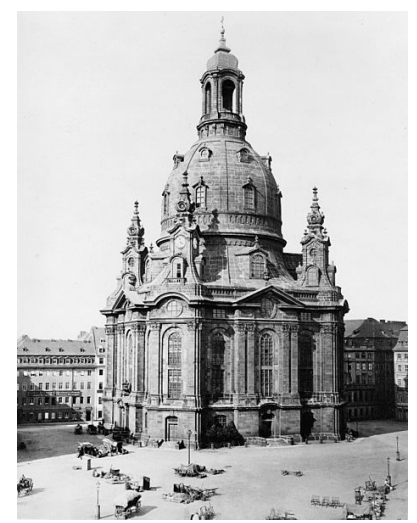

Figure 3. Original Dresden Frauenkirche: Dresden, Germany. 1880. Source: https://upload.wikimedia.org/wikipedia/commons/5/51/ Dresden_Frauenkirche_1880.jpg.

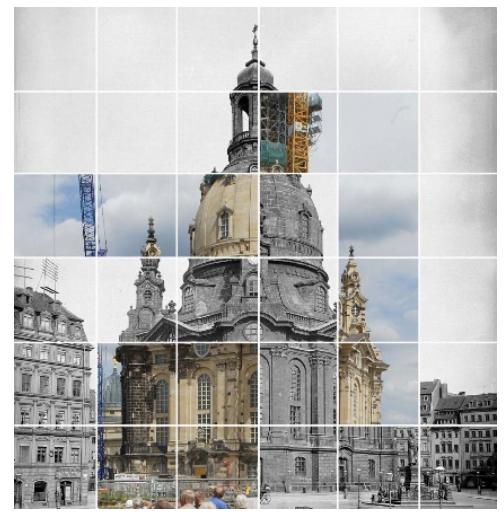

Figure 4. Frauenkirche Reconstruction Collage: Dresden, Germany. Source:

https://thelongandshort.org/assets/images/_articleIma geFullWidth/euro3.jpg. 
Considering the basic idea behind the Frauenkirche reconstruction, it can easily be classified under the "faithful reconstruction" method. However, while most of the stone used for the reconstruction was new, ${ }^{7}$ smaller amounts of the original, dark grey stone were used as well. The fact that no attempts were made in order to restore or clean the original pieces of stone, or to replace it with new stone, provides evidence that the intent behind rebuilt Frauenkirche was not merely to imitate the old one. Old and new stone were used interchangeably in a random stonelaying pattern. Some areas of the façade are dominantly composed out of new stone and vice versa. In this manner, stone usage developed into a design opportunity. However, the material itself was significantly altered from its initial state and therefore it became a design tool which departs from the idea of faithful reconstruction.

Anyhow, this unique usage of stone in the new Frauenkirche can easily be associated with some of the main principles Lebbeus Woods discussed in his writings on reconstruction.

Although faithfully reconstructed, the Church is not a mere copy of what existed before because, in a unique way, it is not striving to simply erase evidence of a violent and unpleasant past. It is rather embracing and honoring it. By supporting the Case Against Erasure ${ }^{8}$, Woods strongly argues that, in order to progress, our modern civilization needs to overcome the urge to suppress and hide painful parts of its history. Thus, even though the reconstruction of the Frauenkirche is not nearly as radical and innovative as Woods would prefer, its subtle embracement of painful history is still in accordance with Woods's theories and beliefs.

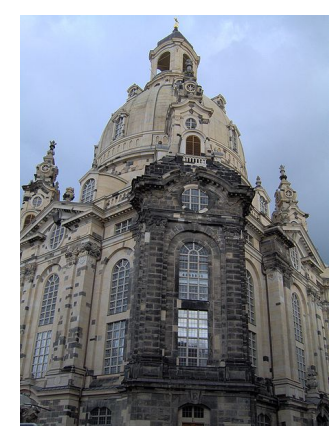

Figure 5. Old and New Stone in Frauenkirche: Dresden: Germany. 2006 Source:

https://upload.wikimedia.org/wikipedia/commo ns/thumb/5/57/FraunkircheSouth.jpg/450px-

FraunkircheSouth.ipg.

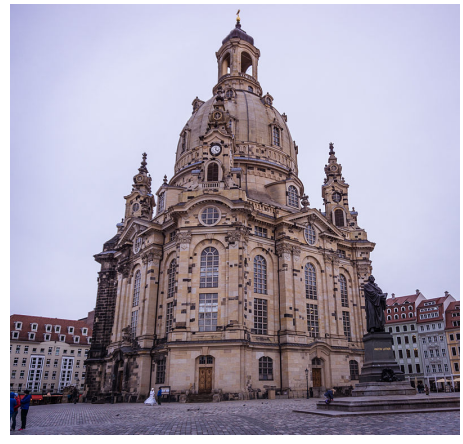

Figure 6. Integration of Foreign Fragment: Dresden, Germany. 2015. Source: https://upload.wikimedia.org/wikipedia/com mons/thumb/1/10/DresdenFrauenkirche_Jan_2015.jpg/800px-DresdenFrauenkirche_Jan_2015.jpg 


\section{Case Study 2: Hiroshima Peace Memorial}

Miraculously, the Hiroshima Production Hall, which was located only $150 \mathrm{~m}$ southeast from atomic bomb explosion epicenter ${ }^{9}$, remained standing while the rest of the city was almost completely destroyed. This fact carries a great metaphorical value which will become a base for its future role in the city.

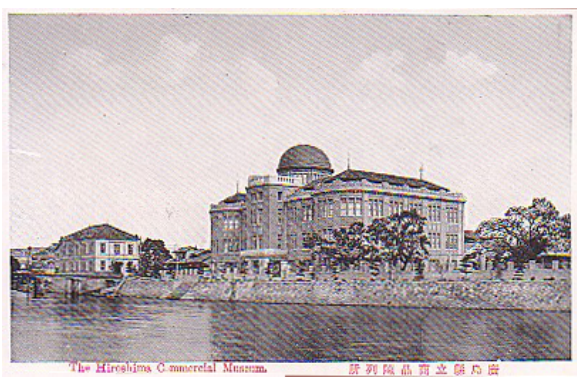

Figure 7. Hiroshima Prefectural Commercial Exhibition Hall, circa 1930's: Hiroshima, Japan. Source: https://upload.wikimedia.org/wikipedia/commons/a/a8/Genbaku_Dome_1.jpg.

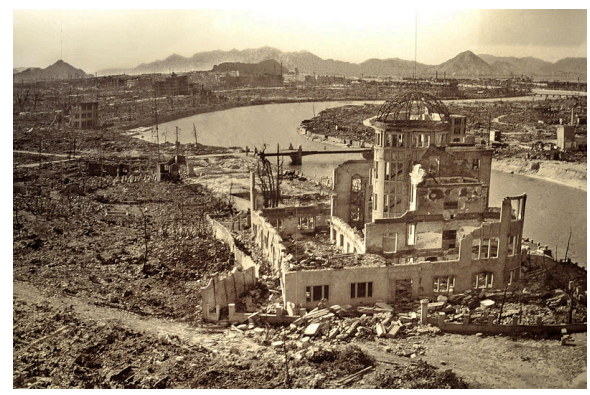

Figure. 8 Hiroshima Production Hall after the Bombing: Hiroshima, Japan. 1945. Source: https://upload.wikimedia.org/wikipedia/commons/2/28/Hiroshima_DSC_3123_\%286248212356\%29.jpg.

The original intent of the Japanese government was to rebuild the entire city landscape. This idea of a complete rebuilding is synonymous with Woods's idea of Erasure ${ }^{10}$ as it strives to suppress part of the national history. However, since the Hiroshima Production Hall was the only building that survived the attack, it was left standing and turned into the Hiroshima Peace Memorial $^{11}$. The philosophy and original thought behind this treatment of the ruin is, in its essence, very similar to the treatment of the Dresden Frauenkirche in the period between 1945 and 1989.

In order to fully understand this approach, it is essential to understand that both Germany and Japan were aggressors during World War II. Therefore, by turning important ruins into war or 
peace memorials, these countries are reflecting on their past collective decisions and actions. In this manner, architecture detaches itself from its original intent and exists as a metaphor for the moral of the story (in this case, the morality of World War II). Additionally, architecture becomes a constant reminder and personification of one whole historic period.

The decisions regarding the future of this ruin were accompanied by a great public debate. Same as in the cases of the Dresden Frauenkirche and the Neues Museum in Berlin, Hiroshima residents disagreed with the government attitude towards this ruin. However, unlike these two buildings, the Hiroshima Production Hall, as an original structure, did not carry a particular importance for the citizens of Hiroshima, nor was it symbolic or spiritual in any way. Regardless of this, a part of the public still demanded for its faithful reconstruction. In this case, the residents had no emotional sentiment towards the building itself, but rather towards the greater urban landscape as it existed prior to the War. Lebbeus Woods explained this citizens' natural reaction to something that is foreign, unpleasant or recalling painful memories in his Case Against Erasure.

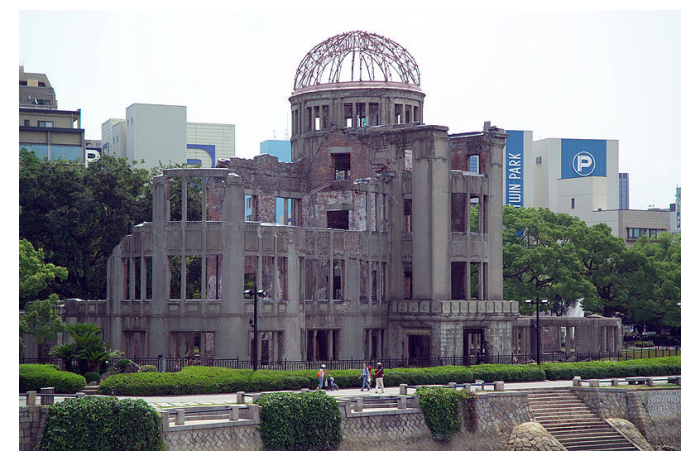

Figure 9. Hiroshima Dome and the View to Memorial Park: Hiroshima, Japan. 2005. Source:

https://upload.wikimedia.org/wikipedia/commons/2/23/Hiroshi maGembakuDome6853.jpg.

However, he also recognized the importance of leaving evidence of such unpleasant basis for creating a new and improved society that is able to build its own future.

\section{Case Study 3: Cadiz Castle}

Even though the Cadiz Castle was not violently destroyed in an armed conflict and therefore it cannot be classified as a post-war reconstruction, it is a valuable case for the study because it exemplifies an alternative philosophical approach to restoration. In addition, the Cadiz Castle is an excellent example of public involvement triggered by redesigned historical structure. 


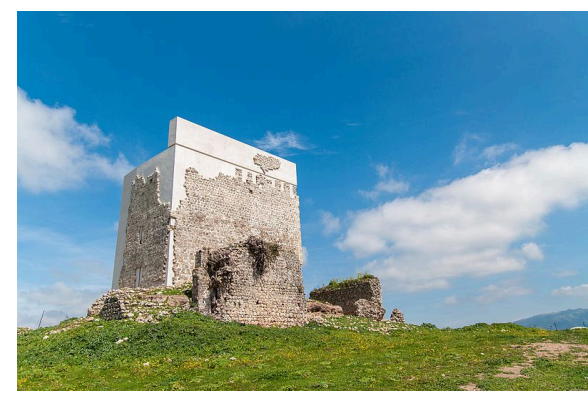

Figure 10. The Tower of Matrera Castle: Cadiz, Spain. 2016. Source:

https://upload.wikimedia.org/wikipedia/commons/thumb/c/c2/C astillo_de_Matrera_en_Villamart\%C3\%ADn.jpg/800pxCastillo_de_Matrera_en_Villamart\%C3\%ADn.jpg

As one of the Cadiz Castle's towers threatened to collapse after more than 1000 years of its existence, local architect Carlos Quevedo was appointed to supervise the restoration process ${ }^{12}$. It is important to note that the structure was in need of restoration, not necessarily reconstruction. This circumstance would trigger a torrent of negative reactions to the new design, as the majority of local residents believed that Quevedo took too much creative liberty. The extent of public unacceptance of the design is best described by the fact that a local group sued the architect for distortion of historic heritage.

In his approach to restoration, Quevedo did not attempt to faithfully restore materials to their previous state. Contrary to this traditional approach, he completely disregarded the idea of faithful historic restoration, and implemented his own ideas of, what will be addressed as the "patching" method. In this way, the Architect honored the site by recognizing the basic quality of past time, its irreversibility. Considering this attitude towards reconstruction, faithful reconstruction can be seen as deceiving as it is almost always trying to manipulate this essential quality of time.

The public involvement in this restoration presents similar evidence as it did in other case studies of this research. All of the cases share a common motive behind public involvement; strong emotional connection and sentiment between local citizens and architecture. Moreover humans tend to be afraid of the unknown and unfamiliar. In an architectural sense, this initial fear can be recognized in many of the world's most famous structures such are the Eiffel Tower and the Pompadour Center in Paris. At the time of their construction, most of the Paris residents were disappointed, furious, and, to a certain extent, disgusted by these unusual and innovative designs. 
Today, we honor these architectural structures as some of the most iconic in the world as they attract countless visitors each year. Similarly, reports show that, since the Cadiz Castle was redesigned, the area records a great increase in numbers of visiting tourists who are attracted primarily by the unusual story behind the Castle.

\section{Case Study 4: Berlin Neues Museum}

Originally, the Neues Museum featured several different architectural styles from various regions of the world and time periods that accompanied the variety of its museum exhibitions. Its architectural complexity and uniqueness is the underlying reason why the residents of Berlin nostalgically looked back at it in the times when the government neglected it. However, this complexity would also become one of the greatest struggles the reconstruction team and architects will needed to address during the redesign and planning process. ${ }^{13}$

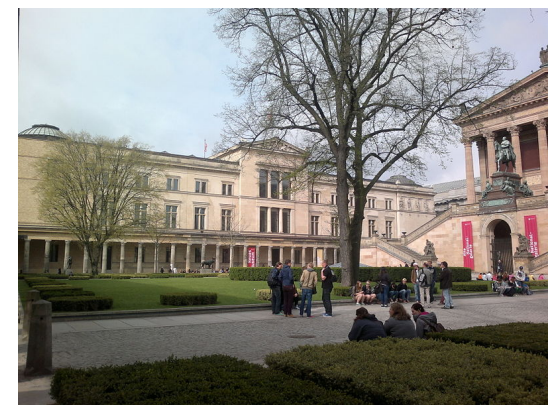

Figure 11. Neues Museum. Berlin: Berlin, Germany. 2014. Source: https://upload.wikimedia.org/wikipedia/commons/thumb/9/9e/N eues_Museum_\%28Berlin\%29.jpg/800px-

Neues_Museum_\%28Berlin\%29.jpg.

The Neues Museum suffered a similar destiny as the Dresden Frauenkirche. ${ }^{14}$ The ruins were left intact, barely secured, for decades as the local government had no interest in re-opening the museum. However, while the Dresden Frauenkirche was almost entirely destroyed with only two walls left standing, the original structure of the Neues Museum was still relatively well preserved. Nevertheless, as the ruins were not protected, both structures went through a severe natural decaying period. Incurred damages from severe weathering conditions would become one of the crucial factors in the Neues Museums consequent restoration process. 


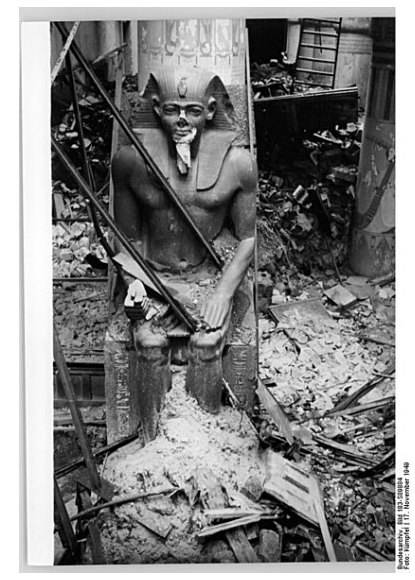

Figure 13. The Neues Museum:

Berlin, Germany. 1945. Source:

https://upload.wikimedia.org/wikipedia/c

ommons/thumb/3/3d/Bundesarchiv_Bild

183-

The reconstruction process of the Neues Museum was somewhat more difficult than those from the other case studies presented in this research. The team working on its renovation needed to combine techniques of restoration, reconstruction and conservation in order to complete this project. As some of the building's parts were less damaged than the others, they only needed careful restoration, while the others that were completely demolished by the bombing, including its famous grand staircase, needed to be rebuilt. Consequently, areas that demanded complete reconstruction opened space for the implementation of new architectural design ideas.

Very similar to the case of Dresden Frauenkirche after the fall of the Berlin Wall in 1989 and the reunification of Germany, excessive public efforts were put into advertising the Neues Museum'sreconstruction. Like Frauenkirche, the Neues Museum was perceived as a cultural icon - a symbol of the entire city. Thus, the excessive public efforts do not surprise, as people merely expressed their basic need for returning of the familiar.

Restoration experts working on the Neues Museum reused some of the original brick that was found on the site. However, the crucial difference in their restoration approach lies in the fact that, while the restorators of Dresden Frauenkirche celebrated the damaged quality of the old stone by randomly combining it with the new one, the old stone in Neues Museum first went through several restoration cleaning processes. Thus, the Neues Museum's reused brick appears to be in the same condition as the new brick, erasing evidence of historical damage and decay.

British architect David Chipperfield won the design competition for the partial reconstruction, and later, in 2011 won the European Union's Prize for Contemporary Architecture. ${ }^{15}$ 
Interestingly, his main competitor was American architect Frank Gehry whose designs were rejected for being too extreme. Other notable architects whose designs were not accepted were Giorgio Grassi, Francesco Venecia and Axel Schultez.

Even before the reconstruction process officially began, several citizen groups organized public protests against Chipperfield's plans. As in the cases of Dresden Frauenkirche, Hiroshima Peace Memorial and Cadiz Castle, the citizens demanded for the absolutely faithful reconstruction. The public idea of reconstruction was, in a certain way, a mere recreation of the lost. Even though Chipperfield initially disregarded these protests, later on he recognized these protests as acts of public involvement in architectural design.

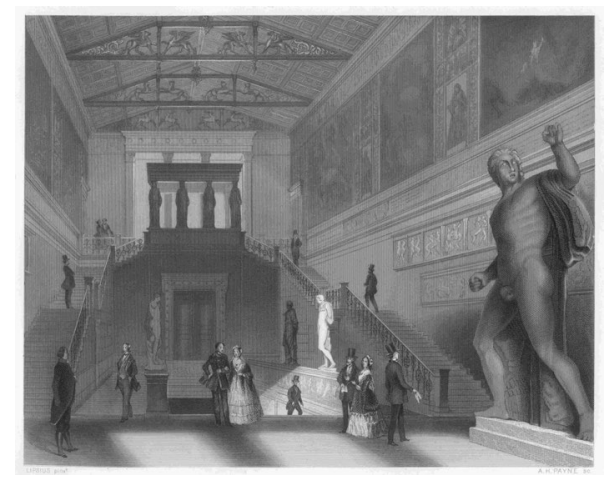

Figure 13. Central Staircase before the Bombing. Berlin, Germany. Source: https://upload.wikimedia.org/wiki pedia/commons/7/72/Treppenhaus

_Neues_Museum_um_1850.jpg.

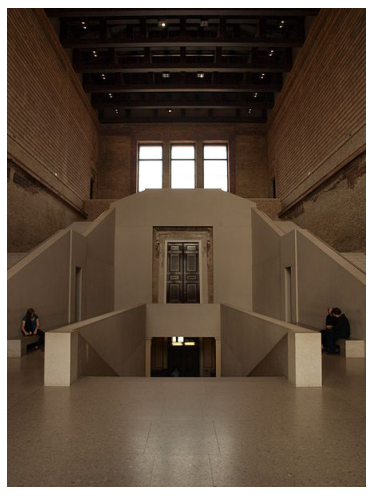

Figure 14. Central Staircase after Reconstruction: Berlin, Germany. 2012. https://upload.wikimedia.org/wikipedia/commons/t humb/2/24/Treppenhaus_im_Neuen_Museum.JPG/ 450px-Treppenhaus_im_Neuen_Museum.JPG.

Chipperfield's approach to reconstruction can be classified as intervention based reconstruction. As seen on the example of the Central Staircase, Chipperfield mostly honors the original structural elements by replacing them with his own, simplified variations. In most cases, his replacements for the original elements are cleaned from all of the "unnecessary" visual decorations, such as color.

There is a significant visual resemblance between Chipperfield's and Quevedo's approaches to reconstruction. Both of their interventions are honoring the original architectural elements by simplifying them into mere volumetric units. However, the Cadiz castle still includes some of the original materials, while Chipperfield's design is based only on the abstract idea of what existed before. 
Considering all the mentioned case studies, Chipperfield's approach to architectural reconstruction is most in accordance with Lebbeus Woods's theories. Chipperfield created architectural interventions that are used as bridges between already existing elements. In a similar way, Lebbeus argued for leaving ruins intact, yet creating architectural interventions that would serve as ideas of how the society can redefine the ways of appreciating and living architecture.

\section{Conclusion}

The issue of architectural post-war reconstruction requires special and very careful approach and consideration, as the adequate solution rarely emerges from designs that are merely aesthetical and practical. In order to be successful, it is essential that post-war architecture addresses cultural, social and moral matters of the area where the new design will be implemented. This is not to say that post-war reconstruction shall lack any innovative thought or that it shall be a mere replication of what existed in the times passed. Indeed, absolute faithful reconstruction can rarely be considered satisfactory as, due to lack of information and knowledge about original techniques and methods, such reconstruction can never reach full accuracy. This theory is best supported by Lebbeus Woods's writings and his Case against Erasure and Case against Restoration. However, as seen in the case study examples presented in this research, it is essential to reach a design balance between innovative thought and public acceptance, because, in the end, such design needs to strive to serve the war scarred community as well as it can. 


\section{References}

Eisele, Gerhard, and Josef Seiler. "Reconstruction of the Neues Museum in Berlin, Germany." Engineering History and Heritage 160, no. EH4 (2012): 221-33.

Faculty of Fine Arts University of Teheran. International Conference on Reconstruction of War-Damaged Areas. Teheran, Iran: University of Teheran Press, 1990.

James, Jason. "Undoing Trauma: Reconstructing the Church of Our Lady in Dresden." Ethos 34, no. 2 (2006): 244-72. Accessed March 20, 2018. https://is.muni.cz/el/1423/jaro2015/SOC763/rd/James-Undoing-Trauma-Reconstruction-Dresden-ETH-2006.pdf.

Matrera Castle." The American Architecture Prize. Accessed March 20, 2018. https://architectureprize.com/winners/winner.php?id=2609.

The Realities of the Atomic Bombing of Hiroshima and the Reconstruction from the A-bomb Damage. Accessed March 20, 2018.

http://www.mayorsforpeace.org/english/whatsnew/news/data/Material_Hiroshima_Abombing_Reconstruction.pdf.

Souto, Ana. Museum Neues Berlin, by David Chipperfield: Completing the past with a Minimalist Intervention. Accessed March 10, 2018. http://irep.ntu.ac.uk/id/eprint/27651/1/PubSub5200_Souto.pdf.

Urra, Susana. "Controversy Erupts over Castle Restoration in Cádiz." El Pais, March 11, 2016. Accessed March 15, 2018. https://elpais.com/elpais/2016/03/11/inenglish/1457696211_872057.html.

Von Clausewitz, Carl. On War. London: N. Trübner, 1873.

W., Jäger, and Carlos A. Brebbia. The Revival of Dresden. Boston: WIT Press, 2000.

Woods, Lebbeus. Radical Reconstruction. New York: Princeton Architectural Press, 1997.

Woods, Lebbeus. War and Architecture. Pamphlet Architecture 15,1993.

\section{Endnotes}

${ }^{1}$ Carl Von Clausewitz, On War, (London, N. Trübner \&, 1873), 61.

${ }^{2}$ Lebbeus Woods. War and Architecture, (Pamphlet Architecture 15, 1993), 10.

${ }^{3}$ Ibid.

${ }^{4}$ Jason James, "Undoing Trauma: Reconstructing the Church of Our Lady in Dresden.", (Ethos 34, no. 2, 2006), 244.

${ }^{5}$ W, Jäger, and Carlos A. Brebbia, The Revival of Dresden, (Boston, WIT Press, 2000), 149.

${ }^{6}$ Ibid., 142.

${ }^{7}$ According to The Revival of Dresden, the new stone was produced using same technique as the old one.

${ }^{8}$ Woods, War and Architecture, (Pamphlet Architecture 15, 1993), 10.

${ }^{9}$ The Realities of the Atomic Bombing of Hiroshima and the Reconstruction from the A-bomb Damage, 2. 
${ }^{10}$ Woods, War and Architecture, (Pamphlet Architecture 15, 1993), 10.

${ }^{11}$ Also known as Atomic Bomb Dome.

${ }^{12}$ Susana Urra, "Controversy Erupts over Castle Restoration in Cádiz.", (El Pais, March 11, 2016).

${ }^{13}$ Gerhard Eisele, and Josef Seiler, "Reconstruction of the Neues Museum in Berlin, Germany.", (Engineering History and Heritage 160, no. EH4, 2012), 221-33. 221.

${ }^{14}$ Part of the city where Neues Museum was located became East Berlin.

${ }^{15}$ Ana Souto. Museum Neues Berlin, by David Chipperfield: Completing the past with a Minimalist Intervention., ( http://irep.ntu.ac.uk/id/eprint/27651/1/PubSub5200_Souto.pdf.) 